\title{
Designing New Strategy for Enhancing Robusta Coffee Production: An Application of Interpretative Structural Modeling
}

\author{
Andi Nuddin1*, Reskiana1, Arman1, Syarifuddin Yusuf2, Nuringsih'2, Muhammad \\ Arsyad 3 , Andi Bustan', Alimuddin Laapo ${ }^{5}$ \\ ${ }^{1}$ Faculty of Agriculture, Universitas Muhammadiyah Parepare, Indonesia. \\ ${ }^{2}$ Faculty of Economic, Universitas Muhammadiyah Parepare, Indonesia. \\ ${ }^{3}$ Faculty of Agriculture, Universitas Hasanuddin, Indonesia. \\ ${ }^{4}$ Faculty of Education, Universitas Palangkaraya, Indonesia. \\ ${ }^{5}$ Faculty of Agriculture, Universitas Tadulako, Indonesia. \\ *Corresponding author's e-mail: andinuddin@umpar.ac.id
}

\author{
How to Cite: Nuddin, A., Reskiana., Arman., Yusuf, S., Nuringsih., Arsyad, M., Bustan, A., and \\ Laapo, A. (2018). Designing New Strategy for Enhancing Robusta Coffee Production: An \\ Application of Interpretative Structural Modeling. Int. J. Agr. Syst. 6(2): 156-163
}

\begin{abstract}
One of the causal factors affect coffee production declining in Indonesia is the decline in harvest area of coffee plants. The decline in the area of coffee farming is caused by the shift of farmers from coffee to other commodities, such as corn, vegetables and fruit. The research was conducted to determine new strategic steps in order to enhance robusta coffee production. To achieve the research objectives, Interpretative Structural Modeling (ISM) analysis and modeling techniques are carried out. This modeling technique does not require a large sample, so the sample used in this study is limited to 22 people from several related agencies. Data processing in research is carried out according to the needs of Interpretative Structural Modeling (ISM) analysis. The results show that the new strategy in developing Robusta coffee production is (1) rehabilitation of coffee plants, (2) rejuvenation of coffee plants, (3) selection of superior coffee varieties, (4) provision of farming roads, (5) coffee price stabilization, (6) intensification of coffee plants, (7) pest control, and (8) increased knowledge of farmers. These new combinations strategy can be strongly expected to enhance robusta coffee production in the country.
\end{abstract}

Copyright $\mathcal{O} 2018$ IJAS. All rights reserved.

\section{Keywords:}

Strategy; Production; Robusta Coffee; ISM

\section{Introduction}

It is a fact that, world coffee needs to increase every year due to coffee has become a commodity of international trade since the 19th century. It should be competitive in the market (Indezere et al., 2018) to enhance production. Since 2014, International Coffee Organization (ICO) showed that the growth of world coffee consumption in the 20082012 period reached an increase of $6.9 \%$ with an average growth of $1.7 \%$ /year. Likewise, the Association of Indonesian Coffee Exporters and Industries, shows that Indonesian coffee consumption also experienced growth, ie the period of 2008-2012 had reached $9.1 \%$ with an average growth of $2.3 \%$ /year (Santoso et al., 2016). The total production of coffee beans produced by Indonesia in 2014 reached more than 600 
thousand tons / year, making Indonesia the third largest coffee producing country in the world after Brazil and Vietnam. In the same year, Indonesia exported coffee to various countries worth US $\$ 588,329,553.00$, so that Indonesia's coffee position became the fourth largest contributor to foreign exchange after rubber, oil palm, and cocoa.

One of the factors causing a decline in coffee production in Indonesia is the shrinking of coffee plantations. The area of Indonesia in 2008 reached 1,295,110 ha, decreasing to $1,235,289$ ha in 2012 with an average decline of $4.62 \%$ or $1.21 \%$ / year (Santoso et al., 2016). Similarly, the use of low-quality seeds has triggered low coffee productivity in Indonesia and affect smallholders income (Arsyad et al., 2016). In general, coffee farmers in Indonesia use seeds originating from seeds, although generative nurseries are easily done at lower costs. Another factor is the existence of farming practices in land classes that are not suitable. Land with a slope of $>15 \%$ without conservation measures, will erode easily and wash the land surface, so that the soil fertility rate will decrease. This will be further aggravated by the existence of management techniques and pest control practices that have not been optimal.

South Sulawesi is also a coffee center in Indonesia after Bengkulu, South Sumatra and Lampung. The results of Alam's (2007) study show that the area of South Sulawesi is an area that has a profitable development opportunity for coffee farming, both robusta coffee and arabica coffee. However, based on the interviews of coffee farmers in Pinrang District (South Sulawesi), it was revealed that the decline in coffee production was a further impact of the decline in the area of coffee farming due to the shift of farmers from coffee to other commodities such as corn, vegetables and fruit. In response to these problems, the government should work together to develop a strategic program that can support increased production, especially robusta coffee. One of the programs includes the need to build and strengthen coffee production institutions, which are expected to be able to realize a strategic program in increasing production. The research objective is to determine new strategic steps in order to enhance robusta coffee production.

\section{Method}

This study aims to determine the strategic program for developing robusta coffee production. The research site was Pinrang Regency, South Sulawesi Province, Indonesia as one of the coffee centers in South Sulawesi. Data obtained in the field were analyzed by applying structured descriptive modeling techniques, namely Interpretative Structural Modeling (ISM). This research was carried out through an expert system approach using a survey method (Eriyatno, 1999). Determination of the sample is done through purposive sampling technique with provisions representing personnel in each field/agency.

Research with the ISM analysis model does not require large sample sizes (Saaty 1988; Eriyatno 1999). The number of experts/practitioners as a sample suggested is quite a number of people with priority who have a level of understanding, mastery, and/or are directly involved in the development of coffee farming. To meet the data needs that can support the achievement of the research objectives, a total sample of 18 consisting of experts/practitioners was distributed to institutions/ agencies related to the development of robusta coffee. Therefore, the respondents in this study consisted of 18 people who were selected purposively from a number of stakeholders both from government agencies, the private sector, and members of farmer groups. 
Data collection is done by observation and interviews using questionnaires. Data analysis techniques are carried out using Interpretative Structural Modeling (ISM) analysis, with stages, namely: (1) Developing Structural Self-Interaction Matrix (SSIM), which is input (assessment) of respondents to the previous sub-elements, as a result of consideration contextual relations, using the symbols $\mathrm{V}, \mathrm{A}, \mathrm{X}$ and $\mathrm{O}$. The symbol $\mathrm{V}$ is given, if the first sub-element 1 is more important than the second sub-element. Symbol $\mathrm{A}$, if the second sub-element is more important than the first sub-element). The $X$ symbol, if the first and second sub elements are equally important, and the O symbol is given if the first and second sub-elements are equally insignificant). (2) Arranging Reachabilitiy Matrix, by changing the symbols $\mathrm{V}, \mathrm{A}, \mathrm{X}$, and $\mathrm{O}$ with numbers 1 and 0 . (3) Arranging the structural model (level of elements) of each element. (4) Compile the Power-Dependent Driver (DP-P) Matrix.

\section{Results and Discussion}

The results of the Interpretative Structural Modeling (ISM) analysis in determining sub-elements as a strategic program as an effort to increase robusta coffee production show that of the 11 sub-elements analyzed, eight of them are strategic programs that have large driver power $(>50 \%)$. The eight sub-elements are four of them in an independent position, and the other four are in the position of linkage, as clearly presented in Table 1.

Table 1. Comparison of Weight of DP-D Program strategy for increasing robusta coffee production.

\begin{tabular}{|c|c|c|c|}
\hline \multirow{2}{*}{ Position } & \multirow{2}{*}{ Sub element } & \multicolumn{2}{|c|}{ Weight } \\
\hline & & $D P$ & $D$ \\
\hline \multirow[t]{5}{*}{ Independent } & 1. Rehabilitation of coffee plants & 0.91 & 0.36 \\
\hline & 2. Rejuvenation of coffee plants & 0.82 & 0.36 \\
\hline & 3. Selection of superior coffee varieties & 0.82 & 0.36 \\
\hline & 4. Provision of farming road & 0.82 & 0.36 \\
\hline & Average & 0.84 & 0.36 \\
\hline \multirow[t]{5}{*}{ Linkage } & 1.Stabilizing coffee prices & 0.82 & 0.73 \\
\hline & 2. Intensification of coffee plant & 0.73 & 0.55 \\
\hline & 3. Pest control & 0.64 & 0.64 \\
\hline & 4. Increased farmer knowledge & 0.55 & 0.82 \\
\hline & Average & 0.69 & 0.69 \\
\hline \multirow[t]{4}{*}{ Dependent } & 1. Increasing the role of extension agents & 0.45 & 0.91 \\
\hline & 2. Provision of production facilities and infrastructure & 0.27 & 0.91 \\
\hline & 3.Strengthening inter-institutional commitment & 0.18 & 1.00 \\
\hline & Average & 0.30 & 0.94 \\
\hline
\end{tabular}

In addition to the weight of the driver power (DP) the importance of the sub-elements as a strategic program in increasing Robusta coffee production is also determined by the dependent weight (D). Comparison of driver power values and dependent on the 11 sub-elements can be shown as in Figure 1. Figure 1 shows that the rehabilitation of coffee plants, rejuvenation of coffee plants, selection of superior coffee varieties, provision of farm roads, and stabilization of coffee prices have a strong driving force (DP) that is an important program to be carried out in an effort to increase robusta 
coffee production. The program position that needs to be done in increasing Robusta coffee production as clearly depicted in Figure 2.

\subsection{Robusta Coffee Development Strategy: Independent Position}

The results of the Interpretative Structural Modeling (ISM) analysis show that there are 4 strategy programs in the independent position. The four programs are (1) Rehabilitation of coffee plants, (2) Rejuvenation of coffee plants, (3) Selection of superior coffee varieties, and (4) Provision of farm roads. The rehabilitation of coffee plants is an important strategic program in order to increase production. This program includes a farming management program, namely branch pruning. This program is becoming increasingly important in old coffee plants with low production.

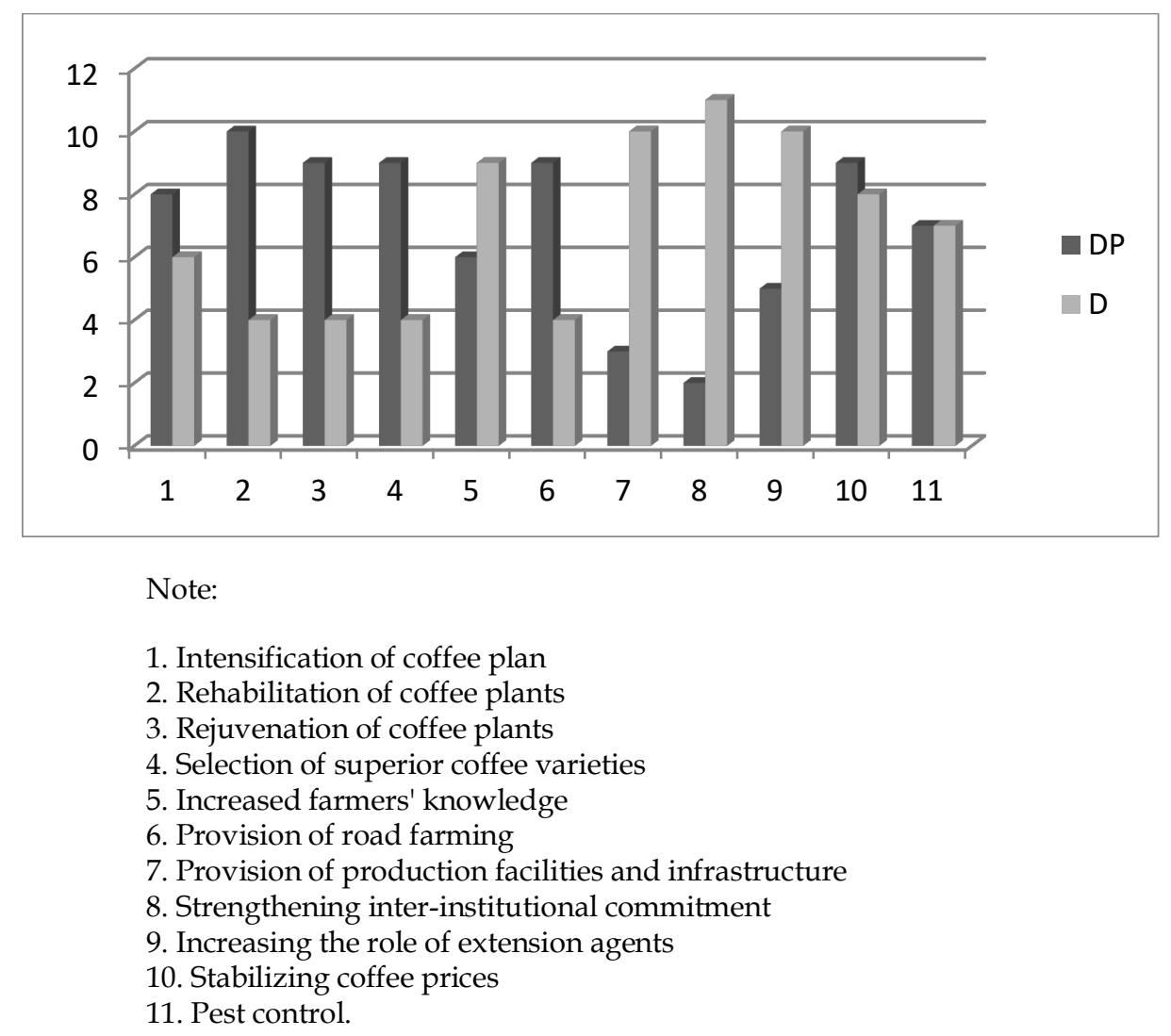

Figure 1. Comparative Diagram of Value of Driver Power (DP) and Dependent (D) Program Strategy for Increasing Robusta Coffee Production.

The next strategy program that is in an independent position is the rejuvenation of coffee plants. Rehabilitation and pruning are inseparable as they are called pruning rehabilitation of old plants. The purpose of coffee crop pruning according to Hulupi and Martini (2013), is (1) To form healthy plants and regulate plant height to facilitate maintenance and harvesting, (2) In robusta coffee to form new production branches in the right amount, (3) Facilitate the entry of light and facilitate the flow of air in the canopy, (4) Facilitate the control of pests and diseases, and (5) Reduce fluctuations in results and the effects of excessive fertilization. 


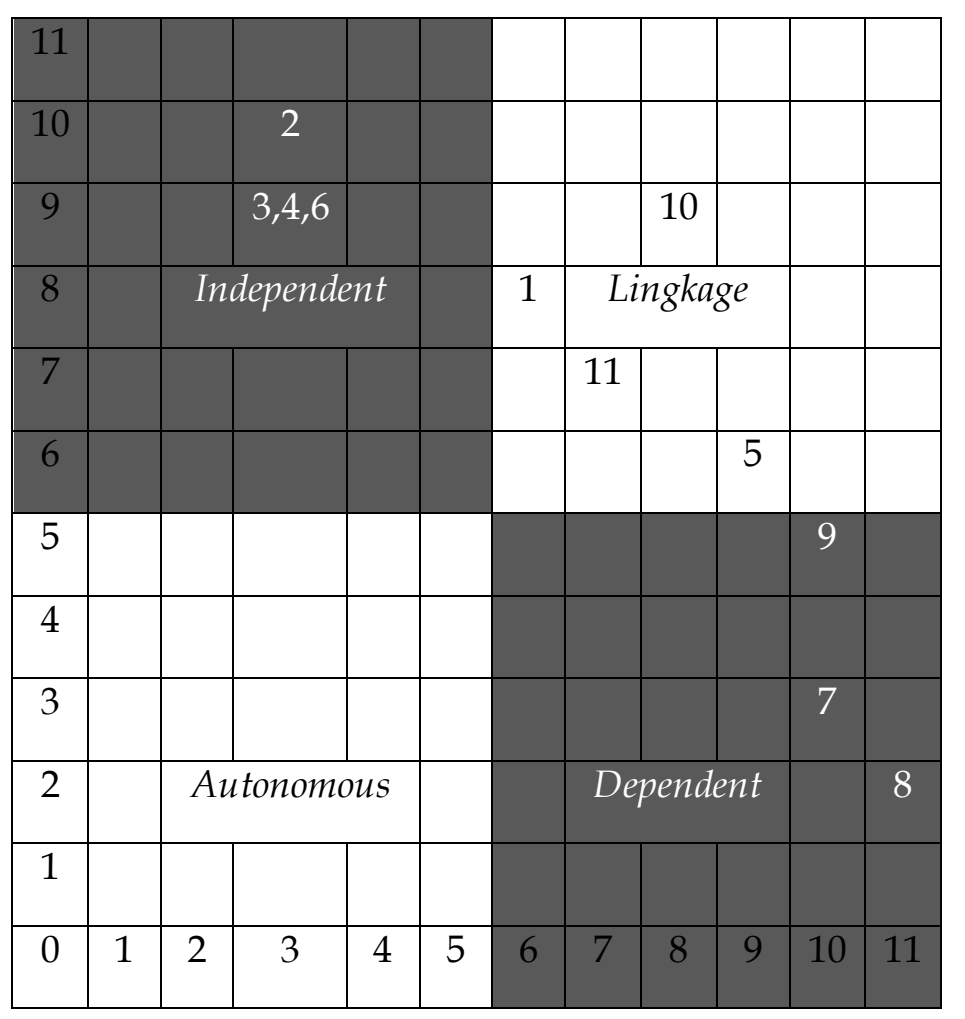

plants

3. Rejuvenation of coffee plants

4. Selection of superior coffee varieties

5. Increased farmers' knowledge

6. Provision of road farming

7. Provision of production facilities and infrastructure

8. Strengthening inter-institutional commitment

9. Increasing the role of extension agents

10. Stabilizing coffee prices

11. Pest control.
Note:

1. Intensification of coffee plants

2. Rehabilitation of coffee

Figure 2. Position of Programs to Increase Robusta Coffee Production

Rejuvenation of coffee plants can be done by replacing plants with superior seeds. As coffee plants grow, these plants are increasingly unproductive. Old coffee plants are also more susceptible to pests and diseases. To overcome this, removing old coffee plants and planting new coffee plants can be the most appropriate solution. This program is the second strategy that is appropriate for older plants. The selection of superior seed varieties is also an important strategic program for increasing coffee production. The selection of superior coffee varieties is needed in order to replace old coffee plants which are characterized by low production. According to Susilawati and Robiartini (2008), to overcome this (low production) can be overcome by the use of superior seeds that are started by repairing nursery media. Besides that, Hulupi and Martini (2013) revealed that specifically robusta coffee nurseries can be done vegetatively by cuttings or connecting. 
The next strategy program in the independent sector is the provision of farm roads. Provision of road farming is a strategic program for the development of robusta coffee farms. Road farmer is a transportation infrastructure in the agricultural/plantation area to facilitate transportation of inputs and agricultural / plantation production.

\subsection{Strategy for robusta coffee production: linkage position}

The results of the Interpretative Structural Modeling (ISM) analysis show that there are 4 strategy programs for increasing robusta coffee production in the lingkage position, namely: (1) coffee price stabilization, (2) coffee plant intensification, (3) pest control, and (4) increasing knowledge of farmers. The first position in the linkage sector is stabilizing coffee prices. The price of unstable coffee is a challenge for farmers to do farming. In the past, the price of coffee was determined by the buyers (bayers market) both at the local level, and at the level of international trade. According to Aklimawati et al (2014), this kind of thing can be overcome if producers/farmers do resistance, namely not selling their coffee until the buyers' stock is depleting. But this strategy is difficult to do in Indonesia because farmers are pressed for daily needs. Because of that the formation of cooperatives is needed to maintain the stability of the selling price of coffee at the farmer level. The intensification of coffee plants is the second strategy program that is positioned in the environment. Intensification means improving the maintenance and maintenance of plants. Coffee plants that are treated intensively will experience optimal growth so that they will produce high productivity farming patterns.

The third strategy program in the lingkage position is pest control. To increase coffee production, it is necessary to control pests as plant destroyers. One of the pests that is very disturbing to coffee farmers in the location is the people's cattle that are kept wildly in the people's garden. Aklimawati's (2014) study also showed that the pattern of livestock raising carried out by the community on the Tambora Sumbawa Slope has the potential to damage coffee plants.

Increasing farmers' knowledge is one of the strategic programs that need to be done in terms of developing robusta coffee production. Increased knowledge of farmers is needed both in terms of crop management, and harvesting and post-harvest. The importance of knowledge about harvesting and post-harvest techniques has been revealed by Edvan et al. (2015), that the quality of coffee is very dependent on harvesting and post-harvest. Coffee picked at the time of old will produce high-quality coffee. Conversely the coffee picked before being red is coffee that is not perfectly cooked so that it will produce an unpleasant aroma and taste.

The results of the ISM analysis show that the increase in farmers' knowledge is in the position of linkage. This means that this program (farmers' knowledge) besides having a very large influence on increase in robusta coffee production, its implementation is very dependent on the role of extension agents as the sub-elements are in a dependent position. 


\subsection{The strategy program is to increase Robusta coffee production in a dependent position}

The results of the Interpretative Structural Modeling (ISM) analysis show that there are 3 strategic programs in the dependent position, including (1) increasing the role of extension agents, (2) providing production facilities and infrastructure, and (3) strengthening commitment between institutions. The strategy program in this position is not free, meaning that it all depends on actions against other sub-elements.

Level 1

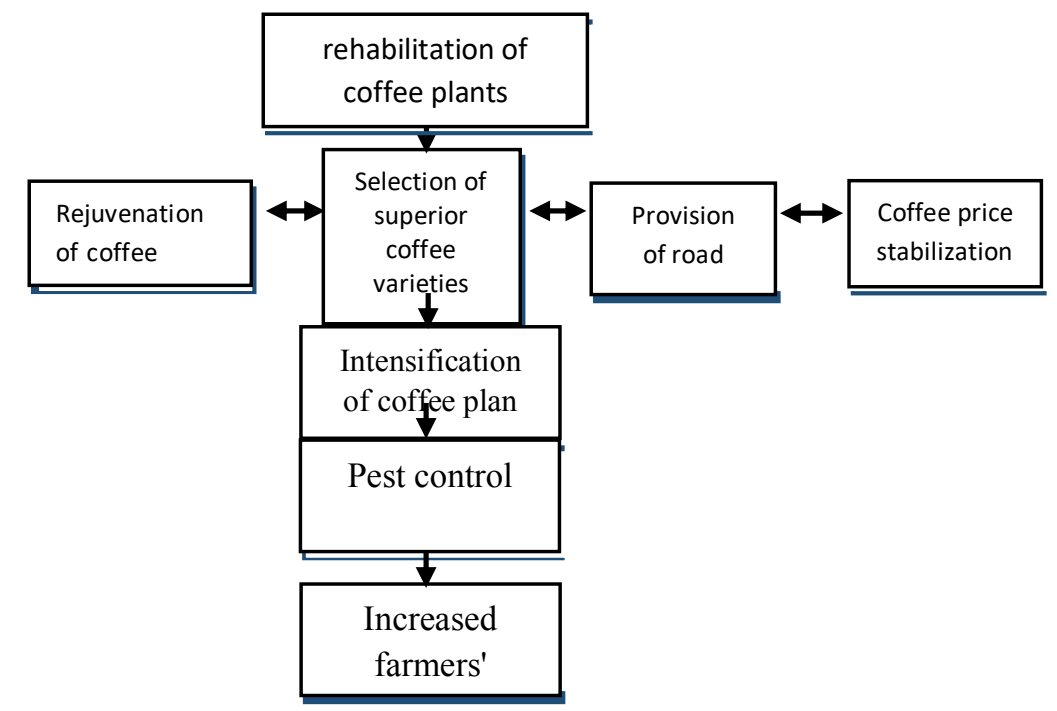

Figure 3. Structure of the Strategy Model to Increase Robusta Coffee Production.

\section{Conclusion}

It can be concluded that the new program in efforts to increase robusta coffee production is rehabilitation of coffee plants, rejuvenation of coffee plants, selection of superior coffee varieties, and provision of farm roads. stabilizing coffee prices, intensification of coffee plants, pest control, increased knowledge of farmers. Among the eight strategic programs, two of them are very urgently required, namely rehabilitation of plants and stabilization of coffee prices. Both of these programs are a rare anticipation of the existence of old coffee plants and the instability of coffee prices that are felt by the farmers.

\section{References}

Aklimawati, L., Yusianto, Surip, M. (2014). Karakteristik Mutu dan Agribisnis Kopi Robusta di Lereng Gunung Tambora, Sumbawa. Pelita Perkebunan. 30(2): 159 180.

Alam, S., (2007). Kelayakan Pengembangan Kopi Sebagai Komoditas Unggulan di Provinsi Sulawesi Selatan. Socioeconomic of Agriculture and Agribusiness. 7, 1-14.

Arsyad, M., Heliawaty, S. Yusuf, Y. Kawamura, (2016). Agricultural DevelopmentMarketing Nexus: Is Tengkulak truly Enemy of Smallholders in Indonesian Rural Area?. Int. J. Agric. Syst, 6(1):60-57 
Edvan, B.T., Rachmat Edison, and Made Same. (2016). Pengaruh Jenis dan Lama Penyangrian pada Mutu Kopi Robusta (Coffea Robusta). Jurnal Agro Industri Perkebunan (AIP). 4 (1):31-40.

Eriyatno. (1999). Ilmu Sistem: Meningkatkan Mutu dan Efektivitas Manajemen. Jilid 1. Bogor: IPB Press.

Hulupi, R., and Endri Martini. (2013). Pedoman Budidaya dan Pemeliharaan Tanaman Kopi di Kebun Campur. Bogor; Indonesia. World Agroforestry Centre (ICRAF) Southeast Asia Rgional Program.

Indzere, Z., Z.Khabdullina, A Khabdullin, D Blumberga, (2018). The benchmarking of chicory coffee's production. Energy Procedia 147 (2018) :631-635.

Saaty TL. (1988). Decision Making for Leaders; The Analytical Hierarchy Process for Decision in Complex World. Pittsburgh: RWS Publications

Santoso, H. R., Cucu, S., and Santi, R., (2016). Respon Pertumbuhan Kopi Robusta (Coffea Robusta) Tercekam Aluminium di Lahan Reklamasi Bekas Tambang Batubara Bervegetasi Sengon (Periode El Nino) Jurnal Agrikultura, 27 (3): 124 131.

Susilawati and Robiartini, L., (2008). Pertumbuhan Bibit Kopi Robusta (Coffe canephora Pierre) Pada Media Kompos Lumpur Sungai. Jurnal Agria, 4 (2): 9 - 11. 